University of New Hampshire

University of New Hampshire Scholars' Repository

$1-20-1994$

\title{
Sulfate and MSA in the air and snow on the Greenland Ice Sheet
}

\author{
J L. Jaffrezo \\ Domaine Universitaire, Grenoble, France \\ C Davidson \\ Carnegie Mellon University \\ M Legrand \\ Laboratoire de Glaciologie et Géophysique de l'Environnement, France \\ Jack E. Dibb \\ University of New Hampshire, jack.dibb@unh.edu
}

Follow this and additional works at: https://scholars.unh.edu/earthsci_facpub

Part of the Atmospheric Sciences Commons

\section{Recommended Citation}

Jaffrezo, J.-L., C. I. Davidson, M. Legrand, and J. E. Dibb (1994), Sulfate and MSA in the air and snow on the Greenland Ice Sheet, J. Geophys. Res., 99(D1), 1241-1253, doi:10.1029/93JD02913.

This Article is brought to you for free and open access by the Earth Sciences at University of New Hampshire Scholars' Repository. It has been accepted for inclusion in Earth Sciences Scholarship by an authorized administrator of University of New Hampshire Scholars' Repository. For more information, please contact Scholarly.Communication@unh.edu. 


\title{
Sulfate and MSA in the air and snow on the Greenland Ice Sheet
}

\author{
Jean-Luc Jaffrezo' and Cliff I. Davidson \\ Department of Civil Engineering, Camegie Mellon University, Pittsburgh, Pennsylvania \\ Michel Legrand \\ Laboratoire de Glaciologie et Géophysique de l'Environnement, St. Martin d'Hères, France
}

Jack E. Dibb

Glacier Research Group, University of New Hampshire, Durham

\begin{abstract}
Sulfate and methanesulfonic acid (MSA) concentrations in aerosol, surface snow, and snowpit samples have been measured at two sites on the Greenland Ice Sheet. Seasonal variations of the concentrations observed for these chemical species in the atmosphere are reproduced in the surface snow and preserved in the snowpit sequence. The amplitude of the variations over a year are smaller in the snow than in the air, but the ratios of the concentrations are comparable. The seasonal variations for sulfate are different at the altitude of the Ice Sheet compared to those observed at sea level, with low concentrations in winter and short episodes of elevated concentrations in spring. In contrast, the variations in concentrations of MSA are similar to those measured at sea level, with a first sequence of elevated concentrations in spring and another one during summer, and a winter low resulting from low biogenic production. The ratio MSA/sulfate clearly indicates the influence of high-latitude sources for the summer maximum of MSA, but the large impact of anthropogenic sulfate precludes any conclusion for the spring maximum. The seasonal pattern observed for these species in a snowpit sampled according to stratigraphy indicates a deficit in the accumulation of winter snow at the summit of the Greenland Ice Sheet, in agreement with some direct observations. A deeper snowpit covering the years 1985-1992 indicates the consistency of the seasonal pattern for MSA over the years, which may be linked to transport and deposition processes.
\end{abstract}

\section{Introduction}

It is now well recognized that oceanic emission of sulfur compounds (mainly dimethylsulfide (DMS)) represents an important source controlling the global sulfur budget in the atmosphere [Andreae, 1986; Bates et al., 1987]. Both laboratory studies [Hatakeyama et al., 1985; Barnes et al., 1988] and measurements performed in the marine boundary layer [Saltzman et al., 1983; Berresheim, 1987; Pszenny et al., 1989; Savoie and Prospero, 1989] have shown that the rapid oxidation of DMS produces particulate methanesulfonic acid (MSA) and non-sea-salt sulfate ( $\mathrm{nsSSO}_{4}{ }^{2-}$ ) via intermediates such as $\mathrm{SO}_{2}$. This part of the sulfur cycle plays an important role in the acidification of natural precipitation [Charlson and Rhode, 1982] and also in the oxidation capability of the atmosphere [Chatfield and Crutzen, 1990; Platt et al., 1990]. Furthermore, the number concentration of

Now at Laboratoire de Glaciologie et Géophysique de 1'Environnement, St. Martin d'Hères, France.

Copyright 1994 by the American Geophysical Union.

Paper number 93JD02913.

0148-0227/94/93JD-02913\$05.00 cloud condensation nuclei $(\mathrm{CCN})$ in the marine environment (controlled in part by the DMS production) can possibly influence the albedo of marine stratus clouds, therefore creating a feedback in the forcing of the global climate [Charlson et al., 1987].

However, some important gaps remain in our knowledge of the sulfur cycle and its global budget, particularly for the high-latitude regions which are very sensitive to climate change and are expected to have large primary productivity [El Sayed et al., 1983]. First, only a few measurements of atmospheric concentrations of MSA and $\mathrm{nsSSO}_{4}{ }^{2-}$ have been conducted in the marine boundary layer south of $50^{\circ} \mathrm{S}$ [Berresheim, 1987; Pszenny et al., 1989; Prospero et al., 1991] or north of $60^{\circ} \mathrm{N}$ [Li et al., 1993].

Second, the atmospheric signals from natural sources are largely perturbed in the high latitudes of the northern hemisphere by anthropogenic inputs, particularly during winter and spring with the formation of Arctic haze [Barrie, 1986]. Although MSA is believed to be a useful tracer of marine emission of DMS and therefore allows evaluation of the respective contribution of marine emissions and anthropogenic activity, we cannot yet quantify these contributions because of a lack of knowledge of the fate of DMS at high latitudes. Indeed, molar MSA/nssSO ${ }_{4}^{2-}$ ratios range from 3 to 
$10 \%$ in marine remote areas at middle and low latitudes [Savoie and Prospero, 1989] but seem to increase at higher latitudes [Berresheim, 1987; Pszenny et al., 1989; Burgermeister and Georgii, 1991; Bates et al., 1992; Li et al., 1993]. This may indicate a change in the rate of oxidation of DMS due to temperature dependence [Hynes et al., 1986], but sampling artifacts cannot be totally ruled out [Bates et al., 1992].

Polar ice cores can provide a unique record of environmental changes and are in this way useful to investigate the respective contributions of marine emissions and anthropogenic inputs and the natural variations linked with climate change. The few studies that investigated MSA and sulfate content of polar ice suggested that the natural sulfur cycle observed in Antarctica is modulated during ENSO developments [Legrand and Feniet-Saigne, 1991] or during cold climatic conditions [Legrand et al., 1991, 1992]. Greenland ice cores revealed a drop of the $\mathrm{MSA} / \mathrm{nssSO}_{4}{ }_{4}^{2-}$ ratio over the last 100 years [Whung et al., 1989], probably related to the increasing impact of fossil fuel burning. Ice core studies can enhance our understanding of the sulfur cycle in high-latitude regions, but little is known about the transfer of MSA and $\mathrm{nsSSO}_{4}{ }_{4}^{2-}$ between the atmosphere and the ice. This knowlegde gap currently limits the interpretation of such records since some studies indicate substantial reworking of the atmospheric signal in shallow ice [Mulvaney et al., 1992].

In this paper we present results from two locations on the Greenland Ice Sheet, with measurements of MSA and $\mathrm{SO}_{4}{ }^{2-}$ in air, surface snow, and snowpit samples, to investigate the transfer of these chemical species from the atmosphere to the ice.

\section{Method}

\section{Programs}

Several series of aerosol, fresh snow, and snowpit samples have been collected on the Greenland Ice Sheet since 1988 for studies conducted at Carnegie Mellon University (CMU). Field work took place during two multicomponent programs focusing on the study of the transfer function of chemical species from source regions to the firm. The Dye $3 \mathrm{Gas}$ and Aerosol Sampling Program (DGASP) took place at Dye 3, a radar station located in the southern part of the Ice Sheet $\left(65^{\circ} 11^{\prime} \mathrm{N} ; 43^{\circ} 50^{\prime} \mathrm{W}\right.$; elevation $\left.2479 \mathrm{~m}\right)$, from August 1988 to July 1989 [Jaffrezo and Davidson, 1993]. This year-round program involved the collection of near-daily aerosol samples together with fresh snow and snowpit samples analyzed for many chemical species. Studies of the climatology and the determination of source regions of the air masses arriving on site were also part of the program [Davidson et al., 1993a].

The second atmospheric program (ATM) has been under way every summer since 1989 at the summit of the Greenland Ice Sheet $\left(72^{\circ} 20^{\prime} \mathrm{N} ; 38^{\circ} 45^{\prime} \mathrm{W}\right.$; elevation $\left.3270 \mathrm{~m}\right)$, with field seasons varying from 2 to 4 months [Jaffrezo et al., 1991]. This program is linked to the American and European deep drilling programs GISP 2 and GRIP that are taking place in the vicinity. As with DGASP, the ATM program is devoted to the study of the transfer functions of chemical species from air to snow, to improve the paleoclimatic interpretation of chemical data retrieved from the nearby deep ice cores.

\section{Aerosol Sampling}

Aerosol samples for the determination of soluble ionic species were collected on Teflon Zefluor filters (pore size 1 $\mu \mathrm{m}$, Gelman Sciences). Several types of filter holders were used, available commercially (from NCAR, Boulder, Colorado) or custom-made for CMU; all were made entirely of high-density polyethylene. The characteristics of the sampling were slightly different during the different experiments, but the collection efficiencies for a given particle size were approximately the same with comparable face velocities of 2 ms-l. The theoretical efficiency exceeds $99.99 \%$ for particles larger than $0.3 \mu \mathrm{m}$ at a face velocity of $0.5 \mathrm{~ms}-1$, according to the manufacturer.

The filter holders were set $1.5-2 \mathrm{~m}$ above the snow surface during sampling, facing down and protected from direct influence of wind and snow by large polyethylene buckets. During both DGASP and ATM the pumps and volumetric meters were located in caves dug under the snow at least 30 $\mathrm{m}$ from the sampling heads. During DGASP the power for the pumps was supplied by the radar station to two sampling sites located $300 \mathrm{~m}$ east and $300 \mathrm{~m}$ west of the main building, respectively; the sites were used alternatively according to the wind direction to minimize contamination from the station [Jaffrezo and Davidson, 1993; Mosher et al., 1993].

During the ATM program, the experiments were conducted at a clean air site located $28 \mathrm{~km}$ sout-southwest of the main GISP 2 camp [Jaffrezo et al., 1991]. Electric power came from an array of solar panels that was upgraded from $1 \mathrm{~kW}$ to $7 \mathrm{~kW}$ between 1989 and 1991. A wind sector controller stopped the sampling when the wind came from the direction of the GISP 2 site or from that of the local camp located 500 $\mathrm{m}$ away from the sampling site. The remaining clean air sector encompassed $90^{\circ}$ to $360^{\circ}$ (true north). The local camp was managed to keep contamination to a minimum: there were a maximum of three persons on site, combustion sources were kept to a minimum (restricted to cooking), and the use of snowmobiles was limited.

Extreme care was also taken to control direct contamination of the filters during handling. No prewashing was needed since the background for major anions and cations is extremely low with this type of filter. Loading and handling of the filters took place under laminar flow benches, with field assistants wearing disposable polyethylene gloves. The loaded filter holders were transported in sealed dust-free double polyethylene bags between the field laboratories and the sampling locations; they were set in sampling position while standing downwind of the filters and wearing full clean-laboratory suits and disposable polyethylene gloves.

After sampling, the filters were processed within 1 week (immediately in the case of DGASP) under a laminar flow bench in the field laboratories. Samples were unloaded and cut in several pieces using a clean surgical knife and Teflon tweezers. The pieces were stored in clean polyethylene bags or in accuvettes (Coultronics) in heat-sealed clean polyethylene bags and kept in the dark at subfreezing temperatures before the analysis back in the main laboratory at CMU. Some of the analyses took place in the field during the ATM program, using the same techniques and contamination control as in the laboratory at CMU. We are presenting here the results of 83,46 , and 82 samples collected during DGASP, ATM90, and ATM91, respectively. 


\section{Fresh Snow Sampling}

Fresh and surface snow samples were collected generally immediately following a snow event leading to some amount of accumulation. Collection took place at locations at least 1 km upwind of any local activity, by a single person wearing full clean suits and disposable polyethylene gloves. Sampling of surface snow was made without the use of any tools, simply scraping the upper layer of snow directly into the collection vial. Great care was taken to sample the fresh snow without collecting older snow underneath. Collection of triplicate samples was made in $125-\mathrm{mL}$ polyethylene vials extensively cleaned with Milli-Q water and double bagged in heat-sealed polyethylene. Samples were kept at subfreezing temperatures before analysis back in the main laboratory. The results of 36 samples collected during DGASP are presented here.

\section{Snowpit Sampling}

Several snowpits were dug during these experiments to assess change in the atmospheric signal during aging of the accumulated snow. Again, the greatest care was taken to prevent contamination: the pits were dug at locations remote from local activities, with personnel wearing the same type of clothing as described above. After excavation of the snowpit, several additional centimeters were shaved from the sampling wall just prior to collection of each sample, using clean polyethylene and plexiglass tools. A sample consisted of six $30-\mathrm{mL}$ polypropylene mailing tubes with screw caps (diameter $1.5 \mathrm{~cm}$ ) that were pushed directly into the wall for sampling. The tubes were prepared and handled according to the same protocol as the vials used for the fresh snow collection. During ATM90 the snowpit was not sampled at fixed depth intervals below the surface. Rather, the stratigraphy of the layers was observed on the wall before sampling, using a backlight pit. The collection of samples within each of the stratigraphic layers is more time consuming than sampling at a fixed interval, but analysis reveals far more details on the seasonality of the deposition and on the firnification processes since layers are well preserved. A deeper snowpit dug during ATM92 was sampled without taking the stratigraphy into account. Samples were collected every $5 \mathrm{~cm}$ with a coring device made of Teflon and stored in air-tight glass bottles; they were processed and analyzed in the same way as other snow samples.

\section{Chemical Analysis}

Analyses of the different types of samples for the determination of $\mathrm{SO}_{4}{ }^{2}$ and MSA were performed with a Dionex 4500 ion chromatograph (IC) and a PAX-100 column. A 26min run allowed complete separation of the peaks of MSA and pyruvic acid, although the latter species was rarely present in snow and acrosol samples. Using the Elab-2 integration package (OMS Corporation, Miami, Florida) and an injection loop of $700 \mu \mathrm{L}$, the typical detection limits were 0.20 and $0.50 \mathrm{ppb}$ for MSA and $\mathrm{SO}_{4}{ }^{2-}$, respectively.

Preparation of the aerosol samples began with the extraction of a piece of filter in a small Teflon beaker. The filter is wetted with $1 \mathrm{~mL}$ of low-sodium grade methanol (J.T. Baker, Phillipsburgh, New Jersey) before the addition of 14 $\mathrm{mL}$ of Milli-Q water. The beaker is shaken by hand at regular intervals for $10 \mathrm{~min}$. The extract is filtered to prevent clogging of the IC column, using Teflon Zefluor filters (pore size, $0.5 \mu \mathrm{m}$; diameter, $13 \mathrm{~mm}$ ) mounted in a precleaned polyethylene filter holder adapted to a syringe. Many tests involving several successive extractions showed that retrieval of major anions and cations (including $\mathrm{MSA}$ and $\mathrm{SO}_{4}{ }^{2}$ ) is always better than $95 \%$ for a single extraction. We preferred to use a single step to minimize potential contamination of the extract.

Separate analyses were performed on two different pieces of each filter to obtain replicate data. Most of the results agreed to within $10 \%$. Many procedural blanks were exposed during each field season, processed and analyzed in the same way as samples. The field blanks for the determination of MSA in the aerosol are essentially below the detection limit of the analysis; the field blanks for $\mathrm{SO}_{4}{ }^{2-}$ vary according to the different experiments, from 7.3 to $28.7 \mathrm{ppb}$. This translates into atmospheric detection limits below 0.1 ngm-3 for MSA and below 10 ngm-3 for $\mathrm{SO}_{4}{ }^{2-}$, for typical conditions achieved in this study, at three times the standard deviation of the blank. Atmospheric concentrations were higher than these detection limits for more than $95 \%$ of the samples. The concentrations presented here are averages of the two measurements and include the correction due to the field blank (most of the time less than 5\% correction for $\mathrm{SO}_{4}{ }^{2-}$ ). They also include correction of the local conditions to obtain concentrations at standard temperature and pressure (STP).

Fresh snow and snowpit samples were thawed at room temperature in their collection vials under a laminar flow bench just before analysis. They were not filtered or concentrated. Analysis of two (in some cases three) vials were conducted for the determination of MSA and $\mathrm{SO}_{4}{ }^{2-}$ in each sample. The results generally agreed to within $15 \%$; arithmetic averages of the measurements are presented here.

Most studies concerning the sulfur budget use non-sea-salt sulfate in their computations. This correction is not applied in our case. Based on the seawater $\mathrm{SO}_{4}{ }^{2-} / \mathrm{Na}$ ratio, the fraction of marine sulfate in the aerosol over the Ice Sheet is small, less than $10 \%$ of the total concentration for most of the year at Dye 3 [Mosher et al., 1993]. Furthermore, the fraction of the sodium effectively coming from the marine source is actually poorly known: a large fraction of the sodium found in snowpits is of crustal origin (up to $50 \%$ insoluble sodium in spring (J.L. Colin, personal communication, 1993)). However, correcting $\mathrm{SO}_{4}{ }^{2-}$ for its sea-salt fraction would slightly enhance the values of $\mathrm{MSA} \mathrm{SO}_{4}{ }^{2-}$, without fundamentally changing the large differences observed between the seasons (see below).

\section{Results and Discussion}

\section{Aerosols During DGASP}

Figure 1 presents the variations in concentration of MSA and $\mathrm{SO}_{4}{ }^{2-}$ and the variations of the ratio $\mathrm{MSA} / \mathrm{SO}_{4}{ }^{2-}$ in the aerosol at Dye 3. The seasonal variation of $\mathrm{SO}_{4}^{2-}$ in the aerosol as well as that of many other chemical species has been extensively discussed in other papers presenting the results from DGASP [Davidson et al., 1993a, b; Dibb and Jaffrezo, 1993; Mosher et al., 1993; Jaffrezo and Davidson. 1991]. The seasonal cycle of aerosol sulfate in the boundary layer of the southern part of the Greenland Ice Sheet is very different from that observed at sea level sites throughout the Arctic. Figure 1 indicates that the atmosphere over the Ice 

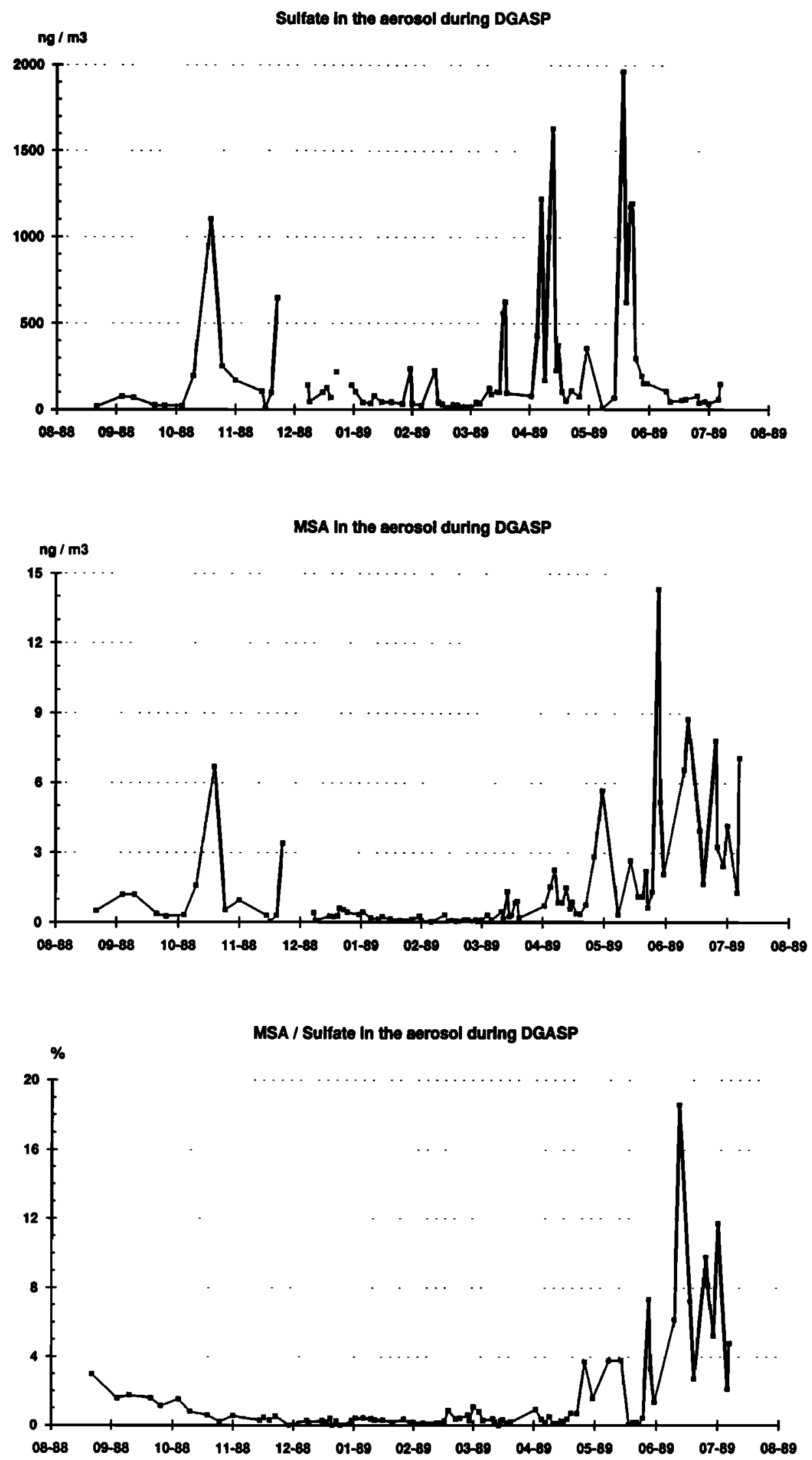

Figure 1. Atmospheric concentrations of $\mathrm{SO}_{4}{ }_{4}^{2-}$ and $\mathrm{MSA}$ and the ratio $\mathrm{MSA} \mathrm{SO}_{4}{ }^{2-}$ during the Dye 3 Gas and Aerosol Sampling Program (DGASP). 
Sheet does not experience Arctic haze that maintains extremely high concentrations of sulfate (several $\mu \mathrm{gm}-3$ for weekly averages) in the low-level Arctic from January to late April [Heidam, 1984; Barrie, 1986; Barrie and Barrie, 1990]. Rather, atmospheric concentrations are low on the Ice Sheet in winter, with averages below $100 \mathrm{ngm}-3$. Higher concentrations are encountered in April-June and again in October but are linked to short-term episodes of transport rather than elevated background. Many source regions can contribute to these episodes, including North America, Europe, and Eurasia [Davidson et al., 1993a,c].

We hypothesize that these differences are due to a combination of factors including elevation, sources, transport, and scavenging. First, Arctic haze layers are principally confined to elevations lower than $2000 \mathrm{~m}$ due to the temperatures and relative humidities in the potential source regions [Bowling and Shaw, 1992]. Also, during most of the period when Arctic haze is present at lower elevations in the Arctic basin (late fall, winter, and early spring), the source regions that influence Dye 3 (at least during the DGASP year) are principally located farther south, over the central Canadian provinces and Northwest Territories, as indicated by 5-day back trajectories [Davidson et al., 1993a]. Furthermore, strong temperature inversions are present over the Ice Sheet [Putnins, 1970], limiting the exchange between the free troposphere, where most of the long-range transport takes place, and the boundary layer where measurements are performed [Dibb and Jaffrezo, 1993]. It is probable that the radiative fog events generally associated with the inversion layers efficiently scavenge the aerosol within the boundary layer [Dibb et al., 1992; Bergin et al., 1993]. The combination of all of these factors leads to low concentrations observed during December to March.

The situation changes in April when the main origin of the back trajectories moves farther north into the Arctic basin [Davidson et al., 1993a], due to changes in general atmospheric circulation. At that time, the atmospheric concentrations in the Arctic basin are still high [Barrie and Barrie, 1990], the strength of the inversion layers on the Ice Sheet is decreasing [Putnins, 1970], and exchange between the free troposphere and the boundary layer seems facilitated [Dibb and Jaffrezo, 1993]. Therefore many episodes of high sulfate concentrations are seen on the Ice Sheet (Figure 1). Nevertheless, their episodic character still dominates, above low background concentrations.

During summer a dramatic change in the atmospheric circulation is experienced, with apparent source regions shifting south of the Arctic basin, with much shorter distances of transport. At that time, many air masses reaching Dye 3 originate over the North Atlantic [Davidson et al., 1993a]. The marine air advected onto the Ice Sheet also brings in extensive precipitation [Putnins, 1970; Ohmura and Reeh, 1991] that favors conditions for efficient scavenging [Borys et al., 1993]. The sulfate concentrations observed in the aerosol over the Ice Sheet are low in summer although there are a few episodes of high concentration in June.

Figure 1 indicates that throughout the DGASP year, some of the episodes that bring above-average concentrations of $\mathrm{SO}_{4}{ }^{2-}$ to Dye 3 are also characterized by elevated levels of MSA, particularly in fall. Nevertheless, the seasonal variations of MSA in the aerosol at Dye 3 are fundamentally different from those of $\mathrm{SO}_{4}^{2-}$.

At sea level in the high latitudes the annual cycle of MSA exhibits a broad maximum in summer but shows some increase in late April; the winter low is reached as early as October [ $\mathrm{Li}$ et al., 1993]. This cycle is dominated by the marine biogenic production of DMS in spring and summer [Davison and Nicholas Hewitt, 1992; Leck et al., 1990] which is minimum in winter. A strong correlation between the increase of the concentrations and the insolation observed at Alert (Canadian Arctic) as well as the similar behavior of some halogen species suggest a rapid oxidation at polar sunrise of MSA precursors accumulated in the Arctic basin during the polar night [ $\mathrm{Li}$ et al., 1993]. Altematively, direct production and transport to the Arctic basin could be another explanation for the early increase seen in spring. Such a bloom associated with high DMS concentrations in seawater was observed as early as April in the Baltic Sea [Leck et al., 1990] and increasing concentrations of MSA in the atmosphere are also seen in April in southern England [Watts et al., 1990].

MSA concentration over the Ice Sheet begins to increase as early as April, with the largest increases taking place in June and July (Figure 1). This pattern is consistent with the main locations of the source regions that are influencing the Ice Sheet, namely, the Arctic basin in spring and the surrounding North Atlantic Ocean in summer. Interestingly, the episodes of higher concentrations of MSA measured at Dye 3 in late October and November are indicative of source regions located farther south, since the biogenic marine sources at latitudes of $55^{\circ}-60^{\circ} \mathrm{N}$ are muted at that time [Davison and Nicholas Hewitt, 1992; Watts et al., 1990; Leck et al., 1990], and atmospheric concentrations of MSA are low [Savoie and Prospero, 1989; Li et al., 1993]. In contrast to the high latitudes the seasonal variation of the MSA concentration is less pronounced in the midlatitudes, with some production in winter [Savoie and Prospero, 1989]. Air mass back trajectories calculated for the two episodes of high concentration on Figure 1 (October 20-25 and November 24 27) are in good agreement with this hypothesis. They show very rapid transport from latitudes as low as $40^{\circ} \mathrm{N}$ within 2 to 3 days (Figure 2).

The variation of the ratio $\mathrm{MSA} / \mathrm{SO}_{4}{ }^{2-}$ during DGASP also shows the influence of several regimes according to the season (Figure 1). During most of the year (late fall to midspring), this ratio is well below $1 \%$ due to low biogenic production of DMS and its low rate of oxidation in the polar night, together with a larger impact of anthropogenic sources of sulfate during the Arctic haze period at sea level [ $\mathrm{Li}$ et al., 1993]. This is also the case at Dye 3, even if the Arctic haze is not as ubiquitous.

Figure 1 shows that the ratio increase to $3-4 \%$ in late April and May. It is only during summer (June throughout August) that values frequently exceed $5 \%$, reaching a maximum of $18 \%$, in agreement with source regions predominantly in the areas arround Greenland and lesser influence of anthropogenic sulfate. Also in agreement with trajectories indicating more southerly source regions for the two episodes in fall, the ratios for these two events are lower than $2-3 \%$.

\section{Aerosols During ATM90 and ATM91}

The interpretation of the results obtained during ATM90 and ATM91 are more limited since the sequences cover only the late spring and summer months. Also, a climatology of trajectories is not available for the site and the seasonality of the source regions is therefore unknown. Nevertheless, one can see comparable patterns as observed at Dye 3 for the late spring-summer months (Figures 3 and 4). Some episodes of 


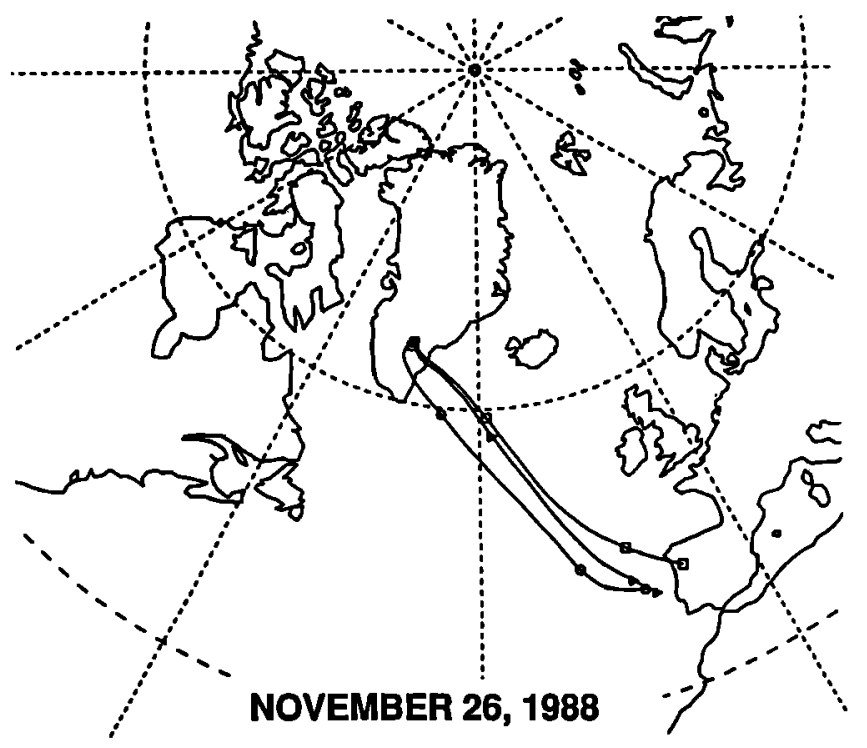

Figure 2. Three-day air mass back trajectories ending over Dye 3 on November 26, 1989 at $775 \mathrm{hPa}$ (squares), $700 \mathrm{hPa}$ (triangles) and $500 \mathrm{hPa}$ (circles).

elevated concentrations of MSA were seen in June and July during ATM90, associated with slightly higher ratios of $\mathrm{MSA} / \mathrm{SO}_{4}^{2-}$ than in Dye 3, that may indicate high latitude source regions. But it is only during the second half of August that this ratio increases substantially and constantly above $10 \%$ (Figure 3 ). The same type of variations were seen during ATM91 (Figure 4), with relatively low concentrations of MSA in June and July, associated with low ratios, despite a large episode lasting several days with ratios up to $30 \%$ in late July. This period is followed by a constant increase of the MSA concentrations and also of the ratios, again during the second half of August. But the earlier part of this field season reveals the existence of a first maximum of the MSA concentrations in late spring. Values of the ratios as high as $30 \%$ clearly indicate the impact of high latitude sources for this period, without the distinct sulfate signal associated with the Arctic haze.

These data may indicate a difference in the pattern of airborne sulfur between Dye 3 and Summit, with a spring maximum more marked, well differentiated from the summer maximum and not necessarily associated with Arctic haze at Summit. The later impact of the summer maximum seems also restricted to August at Summit. Further atmospheric measurements and compilation of back trajectories are under way to investigate this hypothesis and the relation with source regions.

\section{Fresh Snow}

The concentrations of $\mathrm{SO}_{4}^{2-}$ in the surface snow during DGASP (Figure 5) show temporal variation that closely parallel sulfate concentrations in the air (Figure 1). Concentration in both air and snow are at a minimum during the winter, increase in April and June, and then decrease again in summer. However, the ratios of maximum/minimum concentrations are close to 100 for the aerosols while closer to 10 in the snow. The atmospheric signal is therefore somewhat muted in the snow samples, probably due to the dilution effect of the initial step of precipitation events (as always seen with sequential sampling), to the systematic occurrence of precipitation events for meteorological situa- tions that may not be associated with large aerosol concentration, and to the sampling strategy that excludes events with low accumulation (potentially the more concentrated). This last process is also taking place during snowpit sampling if the stratigarphy is not taken into account, with the mixing in the same sample of layers from different origin.

The pattem displayed for the concentrations of MSA (Figure 5) in the snow is also extremely similar to that in the aerosol, with the distinctive minimum in winter, episodes of concentrations above background in April, and strong increases in summer only. The surface snow collected in August-September exhibits relatively high concentrations, but atmospheric measurements are lacking for comparison. It is difficult to consider the respective ranges in concentration in the aerosol and in the snow, as with $\mathrm{SO}_{4}{ }^{2-}$, since lows are below detection limits in both cases.

All these observations indicate that seasonal variation in airborn sulfate and MSA are reasonably well reproduced in the surface snow, for the timing if not for the range of concentrations. On the other hand, the atmospheric range of $\mathrm{MSA} / \mathrm{SO}_{4}{ }^{2-}$ ratio is more accurately reproduced in the snow, indicative of weak, if any, fractionation between the two species during the scavenging and deposition processes. This is consistent with preliminary sampling with impactors during ATM92 and ATM93 (unpublished results) that indicate comparable size distributions for MSA and sulfate, mainly in the submicronic fraction. Clearly more data over the Ice Sheet are needed to determine whether the strong association of MSA with sea-salt particles observed in the marine boundary layer [Pszenny, 1992] is modified over the Greenland ice sheet.

\section{Snow pits}

Figure 6 presents the variations in concentration of $\mathrm{SO}_{4}{ }^{2-}$, MSA, and the ratio $\mathrm{MSA} \mathrm{SO}_{4}{ }^{2-}$ for 81 samples collected in a 1.36-m snowpit $1 \mathrm{~km}$ from the ATM camp, sampled on August 23, 1990. The snowpit was sampled according to stratigraphy as described above; the interrupted horizontal lines in the figure correspond to the different layers that have been identified. 

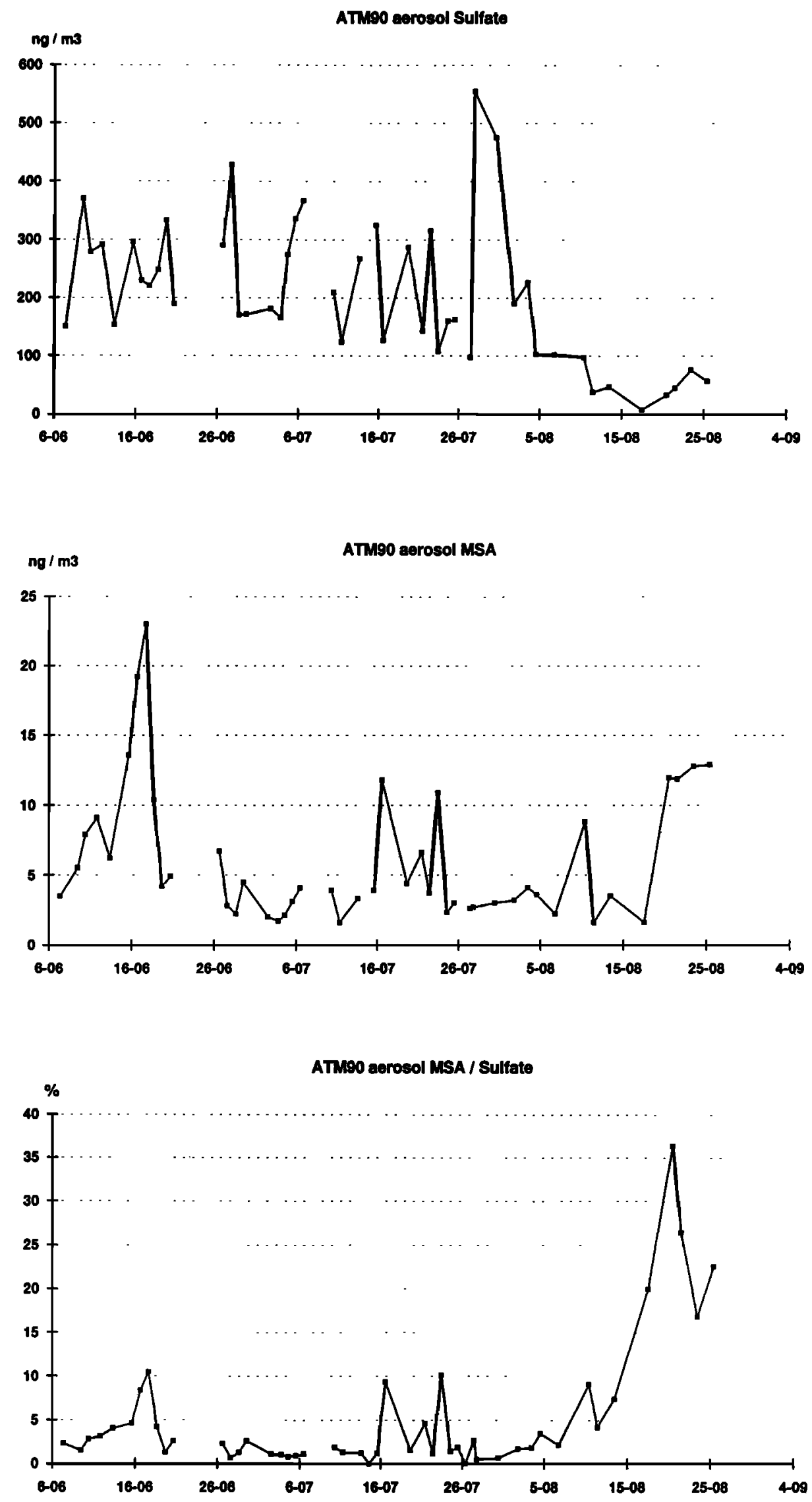

Figure 3. Atmospheric concentrations of $\mathrm{SO}_{4}{ }^{2-}$ and $\mathrm{MSA}$ and the ratio $\mathrm{MSA} / \mathrm{SO}_{4}{ }^{2-}$ during ATM90. 

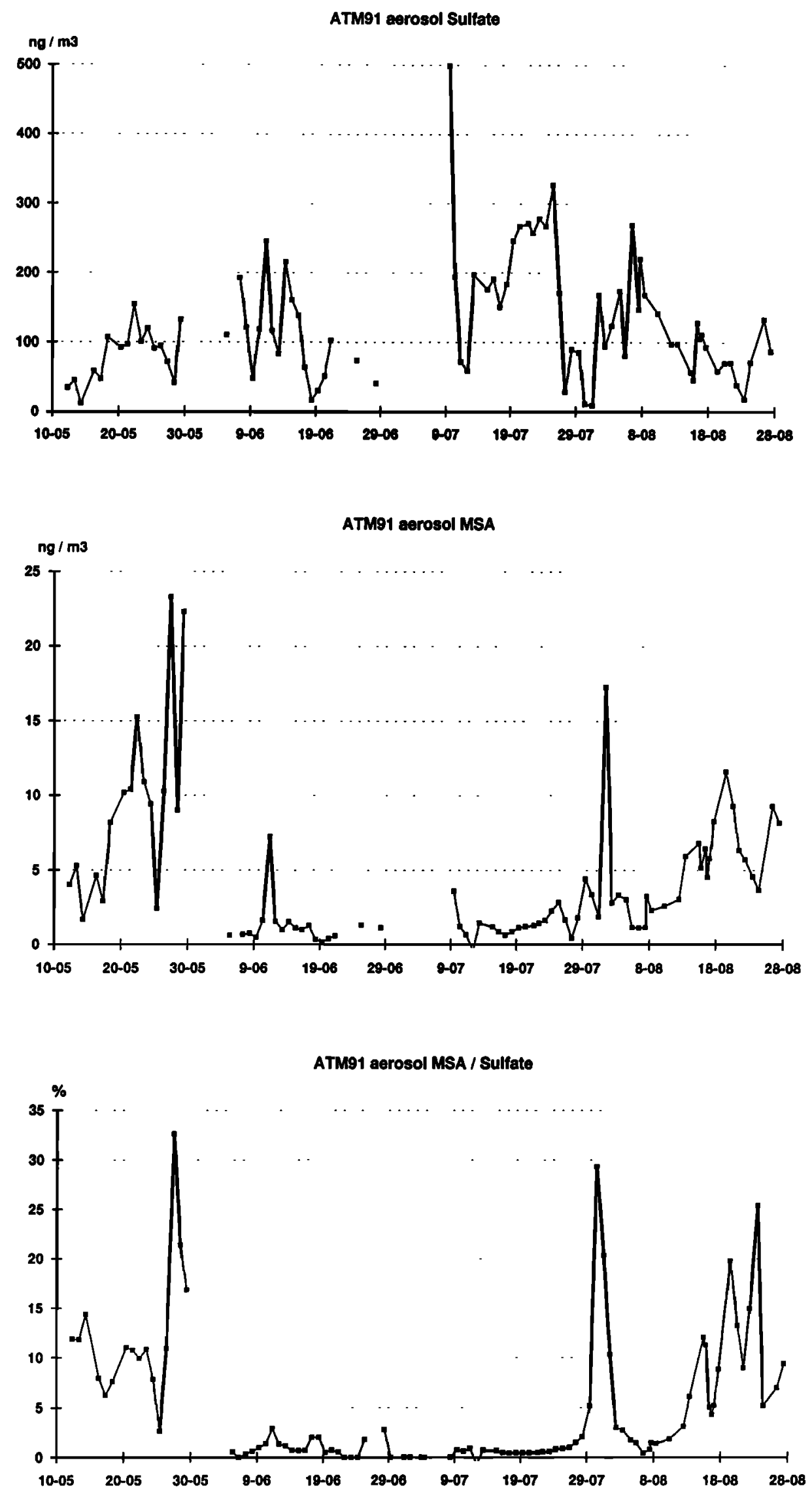

Figure 4. Atmospheric concentrations of $\mathrm{SO}_{4}{ }^{2-}$ and $\mathrm{MSA}$ and the ratio $\mathrm{MSA} / \mathrm{SO}_{4}{ }^{2-}$ during ATM9l. 
DCASP eurtace snow Sulfate

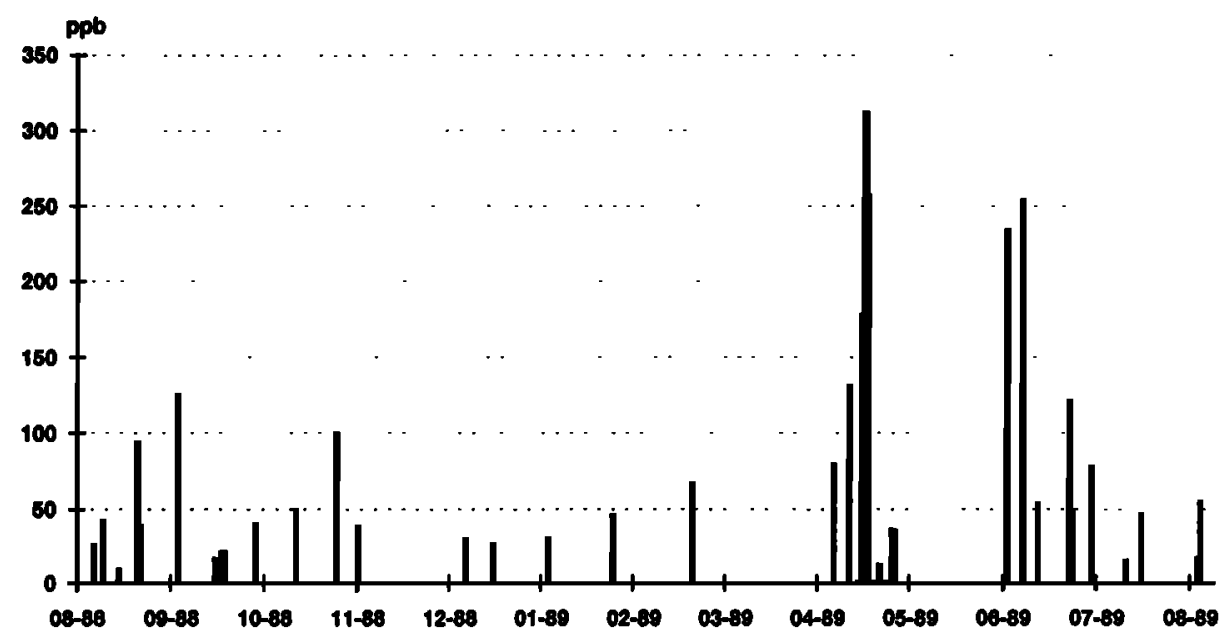

DGASP surface snow MSA

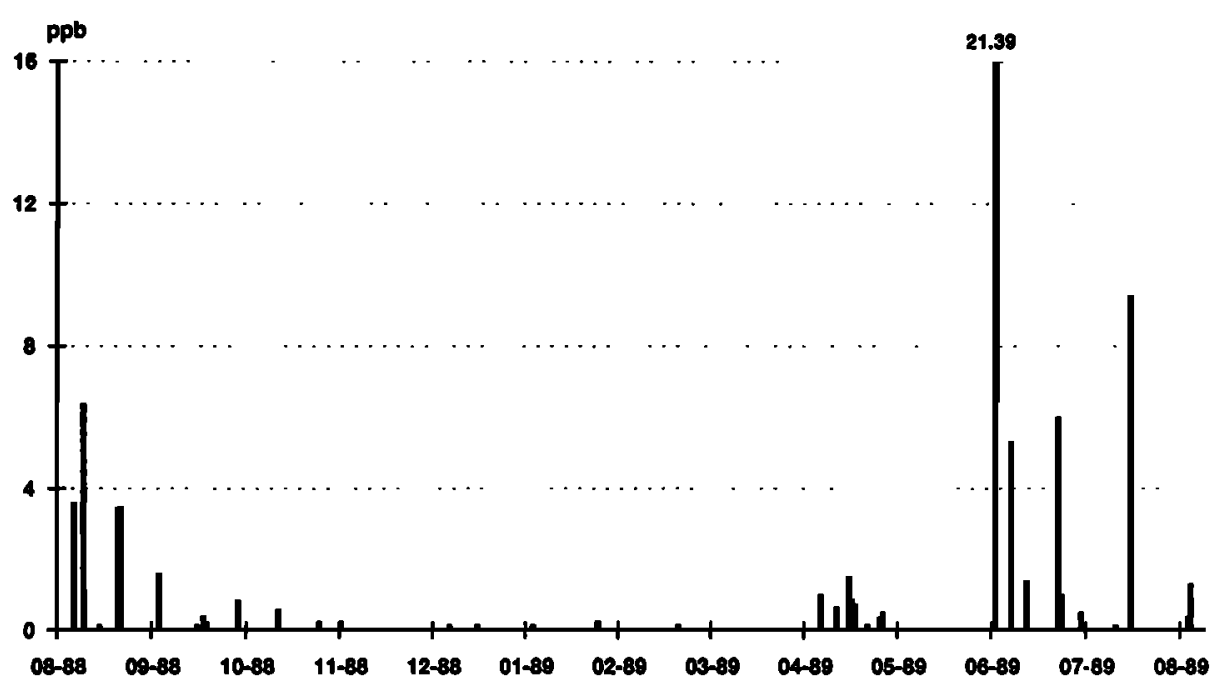

DQASP surface snow MSA / Sulfate

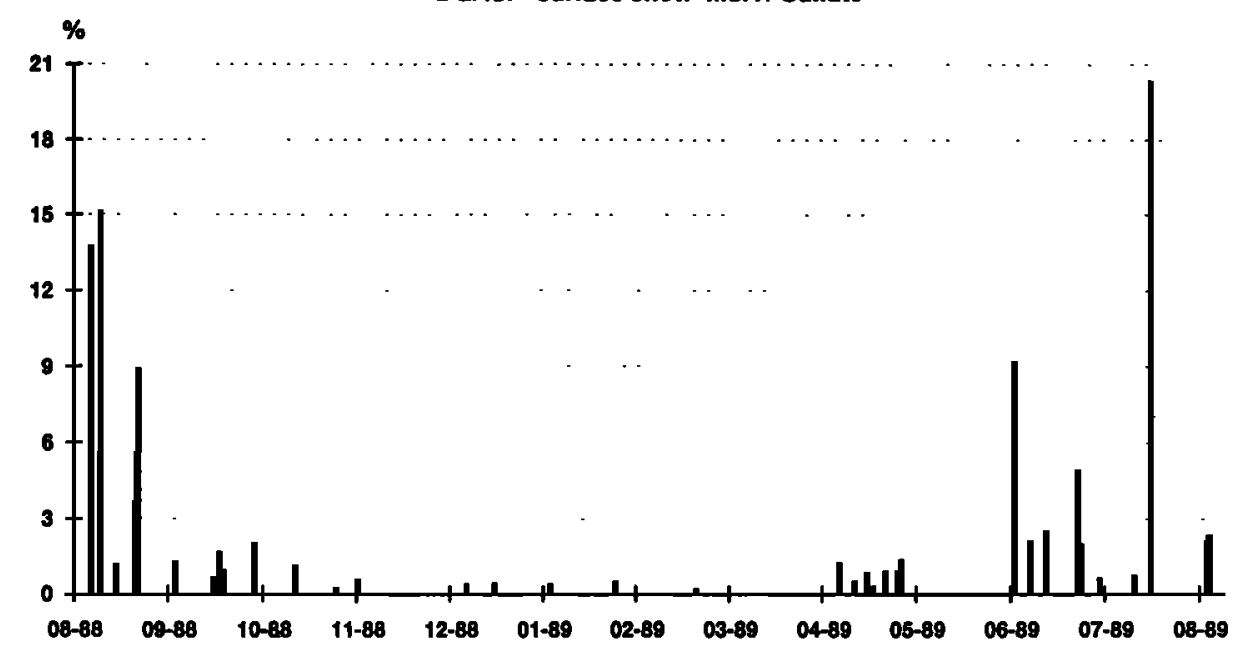

Figure 5. Concentrations of $\mathrm{SO}_{4}{ }^{2-}$ and $\mathrm{MSA}$ and the ratio $\mathrm{MSA}_{\mathrm{SO}}{ }_{4}^{2-}$ in surface snow during DGASP. 

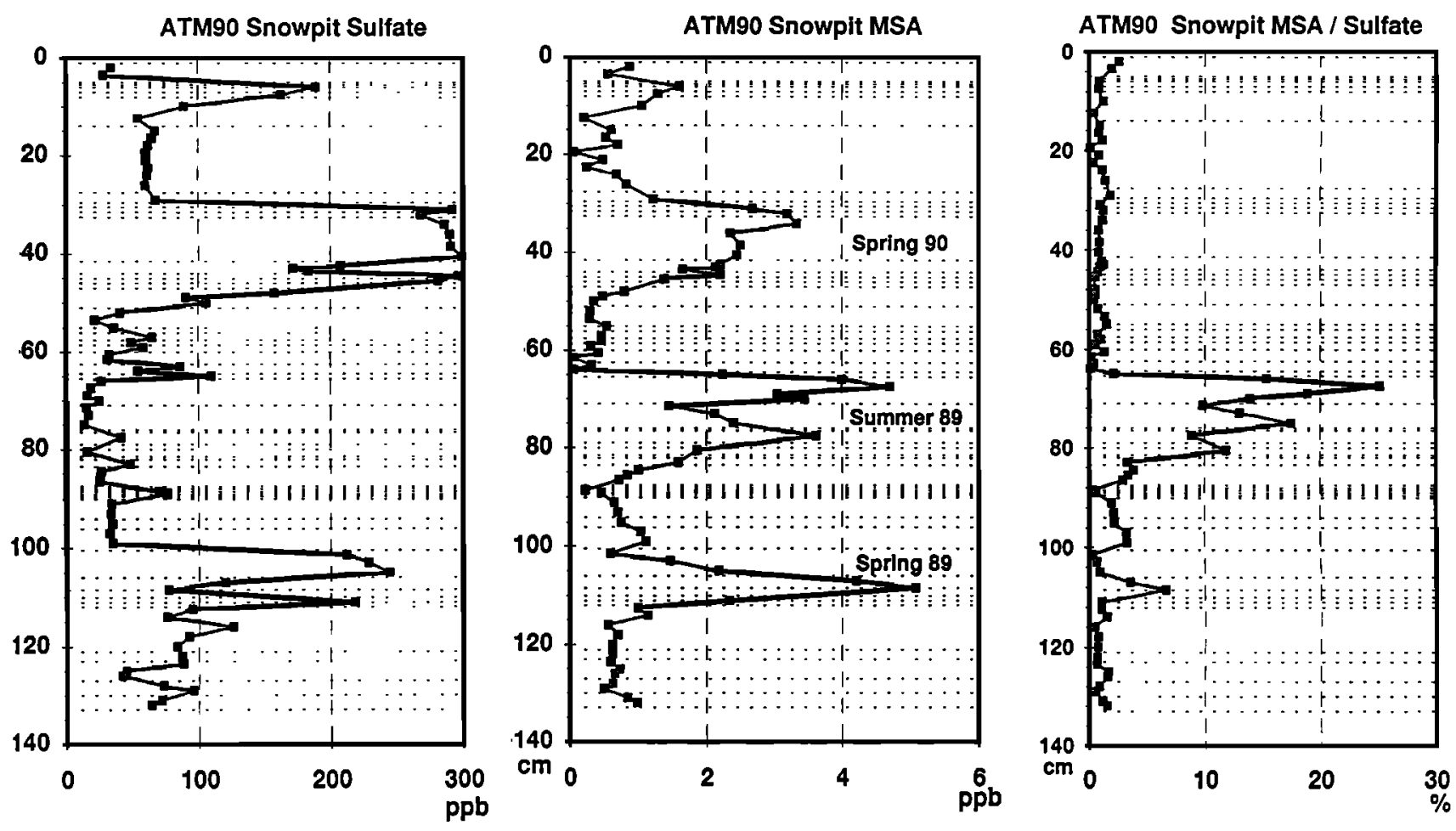

Figure 6. Concentrations of $\mathrm{SO}_{4}{ }^{2-}$ and $\mathrm{MSA}$ and the ratio $\mathrm{MSA} / \mathrm{SO}_{4}{ }^{2-}$ in a snowpit sampled on August 23, 1990. Interrupted horizontal lines represent the stratigraphic layers recorded in the pit. Spring layers are indicated by sulfate maxima.

The differences in concentration and ratios can be extremely large from one layer to another, suggesting low occurrence of mixing between layers after deposition. Therefore the atmospheric signal linked with each accumulation event is well preserved in an individual layer. This is the result of several factors, including the low occurrence of sastrugi in this area, the rapid development of wind crusts that protect the underlying layers, and the fairly large accumulation. The accumulation in this area has been monitored routinely since 1989 as part of the ATM program, with frequent measurements on a network of 100 stakes during the field seasons. Table 1 indicates the yearly average accumulation observed over three seasons. It shows identical accumulation in years 1 and 2 , with a significant decrease in year 3. Also, wide disparities can exist between sites less than $100 \mathrm{~m}$ apart, with a factor of 2 between maxima and minima.

The layers of high concentration of $\mathrm{SO}_{4}{ }^{2-}$ between 30 and $45 \mathrm{~cm}$ from the surface (Figure 6) correspond to the episodes of spring 1990, in reasonable agreement with the accumulation measurements performed since the beginning of that season (Table 1). The large homogeneous layer found between 15 and $27 \mathrm{~cm}$ is not typical of the pattern generally observed in the Summit area but underline the variability of the accumulation that can be observed from site to site. A relative maximum is also observed for concentrations of MSA in the layers from 30 to $45 \mathrm{~cm}$ (Figure 6), in agreement with the hypothesis of a first period of increasing atmospheric concentrations in spring. The upper layers of the pit do not reflect the large increase observed for the MSA concentrations and the ratios in the aerosol (Figure 3), also in agreement with the accumulation measurements that give about $4 \mathrm{~cm}$ of snow only between August 2 and August 19 .

The pit clearly includes the layers deposited during summer 1989. The high concentrations of MSA and ratios above $10 \%$ extending from 65 to $80 \mathrm{~cm}$ below the surface reflect the seasonal patterns found in the aerosols, both at ATM and Dye 3. Agreement is good with the accumulation measurements performed $1 \mathrm{~km}$ away (Table 1). Note that the accumulation associated with the winter season (approximately October to late March) extends at most from 65 to $50 \mathrm{~cm}$. Therefore at least in this case, the accumulation over a 6month period represents less than $20 \%$ of the annual column of snow. Also, the layers deposited during spring 1989 can be found from 100 to $110 \mathrm{~cm}$ below the surface, indicating a large accumulation during spring and summer; if the spring layer is from April to early May and that of summer accumulates mostly during August, as suggested by the aerosols, the 3.5-month accumulation during May-August 1989 is at least equivalent to that of the following winter. Accumulation measurements during DGASP, the only program run continuously for a full year on the Ice Sheet suggest that the accumulation was lower during the winter months. The present study indicates that the same observation might be true in the case of central Greenland as well, where no direct record exists.

The ratios of the maximum to minimum concentrations in the snowpit are close to 15 and 25, for sulfate and MSA, respectively. The same ratios are about 50 and 80 , respective$\mathrm{ly}$, in the aerosol samples, during ATM91; at least for sulfate, one can reasonably postulate that this last ratio will be larger if spring is considered. Therefore the range of the 
Table 1. Accumulation (in Centimeters) at the ATM site Based on Observations of a Deposition Grid of 100 Stakes

\begin{tabular}{lcccccc}
\hline \multicolumn{7}{c}{ Accumulation at the ATM Site, cm } \\
\cline { 2 - 7 } & $06-06-89$ & $06-08-90$ & $06-01-91$ & & \\
& to 06-08-90 & to 06-01-91 & to 06-04-92 & $07-28-89$ & $05-28-90$ \\
& Year 1 & Year 2 & Year 3 & to 08-30-90 & to 08-30-90 \\
\hline Arithmetic mean & 85.5 & 86.2 & 68.5 & 87.4 & 17.2 \\
Arithmetic standard deviation & 9.8 & 9.4 & 7.7 & 6.8 & 5.9 \\
Maximum & 112.0 & 113.5 & 87.5 & 107.5 & 36.0 \\
Minimum & 66.5 & 59.0 & 43.0 & 76.0 & -1.0 \\
\hline
\end{tabular}

atmospheric concentrations is not reproduced in the snowpit samples, as was also observed for the fresh snow during DGASP.

Figure 7 presents results from a deeper (113 samples over $5 \mathrm{~m}$ ) snowpit sampled on July 15 during ATM92, $4 \mathrm{~km}$ from the ATM camp. This pit extends down to winter 1984-1985, as dated with the layers of maximum sulfate concentration in spring. Many studies previously reported this seasonal peak of sulfate and its repeatability from year to year [Mayewski et al., 1990; Whitlow et al., 1992]. The agreement between the two series is much better for sulfate (shape and range of spring maxima of 1990 and 1989) than for MSA, leading, for example, to a much lower ratio $\mathrm{MSA} \mathrm{SO}_{4}{ }^{2-}$ for the summer 1989 in the second pit (depth, $200 \mathrm{~cm})$. Despite such differences, perhaps due to the much larger sampling increment in this last pit, the seasonal structure is clearly apparent, with a double peak for MSA concentrations and yearly maxima close or above $10 \%$ for the ratios.

\section{Conclusion}

Sulfate and MSA concentrations have been measured in the atmosphere, fresh snow and snowpits at two sites on the Greenland Ice Sheet. The seasonal variations in aerosol sulfate are significantly different from those at sea level, with no indication of Arctic haze during winter and episodes of high concentration in spring only. In contrast, the seasonal cycle for MSA is comparable between sea level and Dye 3 [ $\mathrm{Li}$ et al., 1993]. This variation as well as the high ratios $\mathrm{MSA} / \mathrm{SO}_{4}{ }^{2-}$ observed in summer are in agreement with the variations of the source regions indicated by studies of air mass back trajectories [Davidson et al., 1993a], with much larger influence of local sources in summer.

The same seasonal variations are observed in the surface snow at Dye 3, indicating a strong link between the atmospheric boundary layer and the surface snow on a moderate timescale. However, the transfer of the atmospheric signal is
ATM92 Snowpit Sulfate

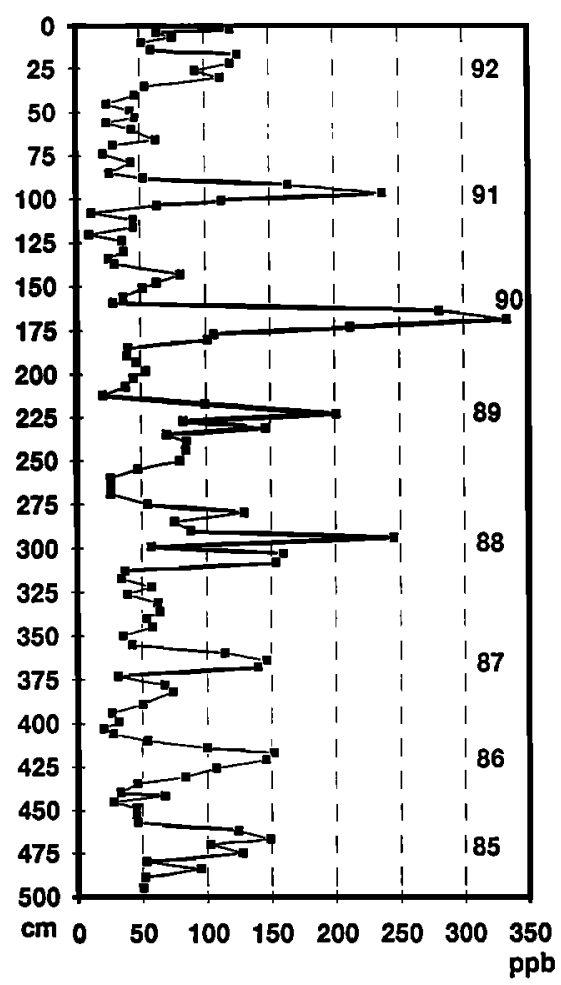

ATM92 Snowpit MSA

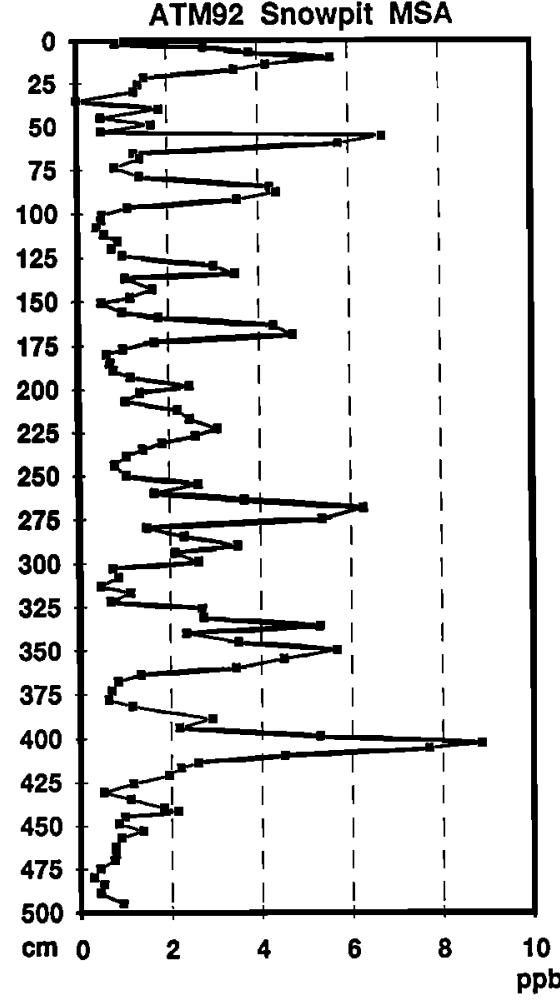

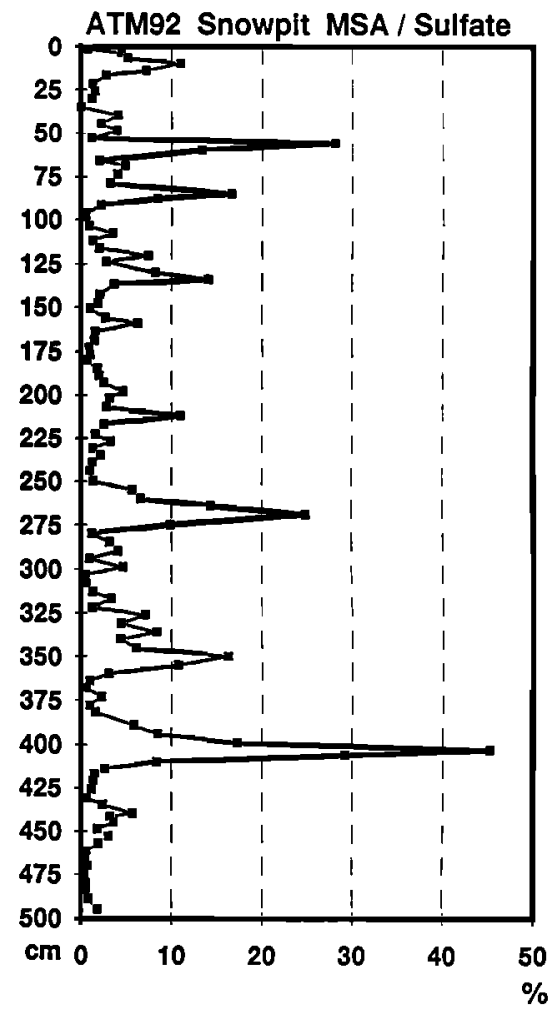

Figure 7. Same as Figure 6, for a snowpit sampled on July 15, 1992. 
not quantitative: ranges in concentrations are much smaller in the snow than in the atmosphere. Part of this result may be due to sampling artifacts, but it underlines the need for a more carefull evaluation of the transfer of chemical species to surface snow for the interpretation of ice core records in terms of atmospheric concentration. On the other hand, the ratios $\mathrm{MSA} / \mathrm{SO}_{4}{ }^{2-}$ are closer between the two phases, indicating little fractionation between the two species during scavenging and deposition.

Analyses of snowpit samples from central Greenland indicate that these seasonalities are well preserved in the upper part of the snowpack. Stratigraphic sampling indicates little mixing between layers coming from separate accumulation events at that site. The seasonnal peaks are very repeatable from year to year indicating a certain permanency of the atmospheric processes, but are represented by very few layers only. This factor is certainly important to explain the variations up to a factor of 2 observed from year to year or place to place on the same year.

However, ascribing the spring peak of sulfate and MSA principally to April and the summer MSA peak to AugustSeptember, as suggested by the aerosol measurements, implies that there is little accumulation of snow in winter, at least during the few years studied. These observations will have to be taken into account in ice core studies which will investigate the poorly known preindustrial sulfur budget in the high northern latitudes.

Aknowledgments. The authors would like to thank all personnel in the field (the Dew Line, GISP-2, PICO, and GRIP communities) for their general support during the DGASP and ATM programs. DGASP was funded by the following grants from the National Science Fundation: DPP8618223, DPP-8821018 and ATM-8922034 (Davidson), and DPP-8821960 (Dibb). Special thanks are going to the GISP-2 Science Management Office and P.A. Mayewski.

\section{References}

Andreae, M. O., The ocean as a source of atmospheric sulfur compounds, in The Role of Air-Sea Exchange in Geochemical Cycling, edited by P. Buat-Mènard, pp. 331-362, D. Reidel, Norwell, Mass., 1986.

Barnes, I., V. Bastian, and K. H. Becker, Kinetics and mechanisms of the reaction of $\mathrm{OH}$ radicals with dimethyl sulfide, Int. J. Chem. Kinet., 20, 415-431, 1988.

Barrie, L. A., Arctic air chemistry: an overview, in Arctic Air Pollution, edited by B. Stonehouse, pp. 5-23, Cambridge University Press, New York, 1986.

Barrie, L. A., and M. J. Barrie, Chemical component of lower tropospheric aerosol in the high Arctic: Six years of observations, J. Atmos. Chem., 11, 211-226, 1990.

Bates, T. S., J. D. Cline, R. H. Gammon, and S. R. KellyHansen, Regional and seasonal variations in the flux of oceanic dimethylsulfide to the atmosphere, $J$. Geophys. Res., 92, (C3), 2930-2938, 1987.

Bates, T. S., J. A. Calhoun, and P. K. Quinn, Variations in the methanesulfonate to sulfate molar ratio in submicrometer marine aerosol particles over the South Pacific Ocean, J. Geophys. Res., 97, (D9), 9859-9865, 1992.

Bergin, M. H., J.L. Jaffrezo, C. I. Davidson, R. Caldow, and J.E. Dibb, Fluxes of chemical species to the Greenland Ice Sheet at Summit by fog and dry deposition, Geochem. Cosmochim. Acta, in press, 1993.
Berresheim, H., Biogenic sulfur emissions from the Subantarctic and Antarctic oceans, J. Geophys. Res., 92, 13,245-13,262, 1987.

Borys, R. D., D. Del Vecchio, J.L. Jaffrezo, C. I. Davidson, and D. L. Mitchell, Assessment of ice particle growth processes at Dye 3, Greenland, Atmos. Environ., in press, 1993.

Bowling, S. A., and G. E. Shaw, The thermodynamics of pollutant removal as an indicator of possible source areas for Arctic Haze, Atmos. Environ., 26A, 2953-2961, 1992.

Burgermeister, S., and H.W. Georgii, Distribution of methanesulfonate, nss sulfate and dimethylsulfide over the Atlantic and the North Sea, Atmos. Environ., 25A, 587-595, 1991.

Charlson, R. J., and H. Rodhe, Factors controlling the acidity of natural water, Nature, 295, 683-685, 1982.

Charlson, R. J., J. E. Lovelock, M. O. Andreae and S. G. Warren, Oceanic phytoplankton, atmospheric sulfur, cloud albedo and climate, Nature, 326, 655-661, 1987.

Chatfield, R.B., and P.J. Crutzen, Are the interactions of iodine and sulfur species in marine air photochemistry ?, J. Geophys. Res., 95, 22,319-22,341, 1990.

Davidson, C. I., J.L. Jaffrezo, M. J. Small, P. W. Summers, P. M. Olson, and R. D. Borys, Trajectory analysis of source regions influencing the south Greenland Ice Sheet during the Dye 3 Gas and Aerosol Sampling Program, Atmos. Environ., in press, 1993a.

Davidson, C. I., et al., Chemical constituents in the air and snow at Dye 3, Greenland. I: seasonal variations, Atmos. Environ., in press, 1993 b.

Davidson, C. I., et al., Chemical constituents in the air and snow at Dye 3, Greenland. II: analysis of episodes in April 1989, Atmos. Environ., in press, 1993c.

Davison, B., and C. Nicholas Hewitt, Natural sulphur species from the North Atlantic and their contribution to the United Kingdom sulphur budget, J. Geophys. Res., 97, (D2), 2475-2488, 1992.

Dibb, J. E., and J.L. Jaffrezo, Beryllium-7 and Lead-210 in aerosol and snow in the Dye 3 Gas and Aerosol Sampling Program, Atmos. Environ., in press, 1993.

Dibb, J. E., J.L. Jaffrezo, and M. Legrand, Initial findings of recent investigations of air-snow relationships in the Summit region of the Greenland Ice Sheet, J. Atmos. Chem., 14, 167-180, 1992.

El Sayed, S. Z., D. C. Bigg, and O. Holm-Hansen, Phytoplankton standing crop, primary productivity, and near-surface nitrogeneous nutrient fields in the Ross Sea, Antarctica, Deep Sea Res., 80, 871-886, 1983.

Hatakeyama, S., K. Izumi, and H. Akimoto, Yield of $\mathrm{SO}_{2}$ and formation of aerosol in the photo-oxidation of DMS under atmospheric conditions, Atmos. Environ., 19, 135141, 1985.

Heidam, N. Z., The components of the Arctic aerosol, Atmos. Environ., /8, 329-343, 1984.

Hynes, A. J., P. H. Wine, and D. H. Semmes, Kinetics and mechanisms of $\mathrm{OH}$ reactions with organic sulfides, $J$. Phys. Chem., 90, 4148-4156, 1986.

Jaffrezo, J.L., and C. I. Davidson, Sulfate in the air, surface snow and snowpits at Dye 3, Greenland, in Precipitation Scavenging and Atmosphere-Surface Exchange, edited by S.E. Schwartz and W.G.N. Slinn, Hemisphere Publishing Company, Washington D. C., pp. 1693-1703, 1991.

Jaffrezo, J.L., and C. I. Davidson, The Dye 3 Gas and Aerosol Sampling Program: an overview, Atmos. Environ., in press, 1993. 
Jaffrezo, J.L., J. E. Dibb, and C. I. Davidson, GISP 2 studies of the atmosphere and surface snow at Summit, Greenland, Eos Trans. $A G U, 72,250-251,1991$.

Leck, C., U. Larsson, L. E. Bagander, S. Johansson, and S. Hajdu S, Dimethyl Sulfide in the Baltic Sea: Annual variability in relation to biological activity, J. Geophys. Res., 95, (C3), 3353-3363, 1990.

Legrand, M., C. Feniet-Saigne, E. S. Saltzman, C. Germain, N. I. Barkov, and V. N. Petrov, Ice-core record of oceanic emissions of dimethylsulphide during the last climatic cycle, Nature, 350, 144-146, 1991.

Legrand, M., and C. Feniet-Saigne, Methanesulfonic acid in south polar snow layers: A record of strong El Nino ?, Geophys. Res. Lett., 18, 187-190, 1991.

Legrand, M., C. Feniet-Saigne, E. S. Saltzman, and C. Germain, Spatial and temporal variations of methanesulfonic acid and non-sea-salt sulfate in antarctic ice, J. Atmos. Chem., 14, 245-260, 1992.

Li, S. M., R. W. Talbot, L. A. Barrie, R. C. Harriss, C. I. Davidson, and J.L. Jaffrezo, Seasonal and geographic variations of methanesulfonic acid in the Arctic troposphere, Atmos. Environ., in press, 1993.

Mayewski, P. A., M. J. Spencer, M. S. Twickler, and S. Whitlow, A glaciochemical survey of the Summit region, Greenland, Ann. Glaciol. 14, 186-190, 1990.

Mosher, B. W., P. Winkler, and J.L. Jaffrezo, Seasonal trends in aerosol chemistry at Dye 3, Greenland, Atmos. Environ., in press, 1993.

Mulvaney, R., E. C. Pasteur, D. A. Peel, E. S. Saltzman, and P.Y. Whung, The ratio of MSA to non-sea-salt sulphate in Antarctic Peninsula ice cores, Tellus, 44B, 295-303, 1992.

Ohmura, A., and N. Reeh, New precipitation and accumula tion maps for Greenland, J. Glaciol., 37, 140-148, 1991.

Platt, U., G. Lebras, G. Poulet, J.P. Burrows, and G. Moortgat, Peroxy radicals from night-time reactions of $\mathrm{NO}_{3}$ with organic compounds, Nature, 348, 147-149, 1990.

Prospero, J. M., D. L. Savoie, E. S. Saltzman, and R. Larsen, Impact of oceanic sources of biogenic sulphur on sulfate aerosol concentrations at Mawson, Antarctica, Nature, 350, 221-223, 1991.
Pszenny, A. A. P., Particle size distributions of methanesulfonate in the tropical Pacific marine boundary layer, J. Atmos. Chem., I4, 273-284, 1992.

Pszenny, A. A. P., A. J. Castelle, J. N. Galloway, and R. A. Duce, A study of the sulfur cycle in the Antarctic marine boundary layer, J. Geophys. Res., 94, 9818-9830, 1989.

Putnins, P., The climate of Greenland, in Climats of the Polar Regions, World Survey of Climatology, edited by S. Orvig, Elsevier, New York, 1970.

Saltzman, E. S., D. L. Savoie, R. G. Zika, and J. M. Prospero, Methane sulfonic acid in the marine atmosphere, J. Geophys. Res., 88, 10,897-10,902, 1983.

Savoie, D. L., and J. M. Prospero, Comparison of oceanic and continental sources of non-sea-salt sulphate over the Pacific Ocean, Nature, 339, 685-687, 1989.

Watts, S. F., P. Brimblecombe, and A. J. Watson, Methanesulphonic acid, dimethyl sulphoxide and dimethyl sulphone in aerosols, Atmos. Environ., 24A, 353-359, 1990.

Whitlow, S., P. M. Mayewski, and J. E. Dibb, A comparison of major chemical species seasonal concentration and accumulation at the South Pole and Summit, Greenland, Atmos. Environ., 26A, 2045-2054, 1992.

Whung, P.-Y., E. S. Saltzman and M. J. Spencer, A 200-year methanesulfonic acid record from the South Greenland ice core, Eos Trans. AGU, 70, 1151, 1989.

C. I. Davidson and J.-L. Jaffrezo, Department of Civil Engineering, Carnegie Mellon University, Pittsburgh, PA, 15213. (e-mail: cd0w@andrew.cmu.edu; jlj@glaciog.grenet.fr)

M. Legrand, Laboratoire de Glaciologie et Géophysique de l'Environnement, Rue Molière, BP 96, St. Martin d'Hères Cedex, 38 402, France.

J. E. Dibb, Glacier Research Group, Institute for the Study of Earth, Ocean and Space, University of NewHampshire, Durham, NH, 03824. (e-mail: jack_dibb@grg.unh.edu)

(Received May 11, 1993; revised October 13, 1993; accepted October 15, 1993.) 